\title{
The Effect of Brand Awareness and Brand Image on Repurchase Intention through Brand Loyalty in Beach Tourism in East Java, Indonesia
}

\author{
Christina Esti Susanti
}

\begin{abstract}
This research was conducted to test and analyze the influence of brand awareness and brand image on repurchase intention through brand loyalty on beach tourism in East Java, Indonesia. The sampling technique in this study uses sampling quota and sample characteristics are consumers who have visited one of the beaches that are generally known in East Java, Indonesia and a minimum age of 21 years. The sampling technique used is non probability sampling. The sample studied was 200 respondents. The analytical tool used is SEM analysis.This study proves all the hypotheses proposed in this study, namely: Brand awareness has a significant effect on brand loyalty, Brand image has a significant effect on brand loyalty, Brand loyalty has a significant effect on repurchase intention, Brand awareness has a significant effect on repurchase intention through brand loyalty, and Brand image has a significant effect on repurchase intention through brand loyalty, are accepted. Academic advice is proposed for future research on the influence of brand awareness, brand image, brand loyalty, and repurchase intention. It is recommended to be tested on different objects to test the firmness of these theories. While practical advice is submitted to beach tourism managers especially those who are the object of this research should pay attention to information conveyed through: television, newspapers, magazines, and the internet, the annual routine festival agenda, unique image, popularity, environmental sustainability, because based on research results it has a positive and significant effect on loyalty and intention to repeat visits.
\end{abstract}

Key words: Brand Awareness, Brand Image, Brand Loyalty, Repurchase Intention

\section{INTRODUCTION}

\section{A. Background}

In the current era, tourism is a lifestyle that is in great demand. Even tours can show someone's identity indirectly, so it is not surprising if there are those who are willing to save for traveling. The development of the tourist world has become important in various circles, both young and old. Many people who want to do tours and different from others, especially in association, travel experience is important to note. The development of the tourist world has experienced a period of rapid revolution in Indonesia. These developments have positive and negative effects. One of the positive impacts of tourism is that tourists can always look attractive with the tourist experiences they share with their relations.

Revised Manuscript Received on September 22, 2019.

Christina Esti Susanti, Faculty of Business, Widya Mandala Catholic University Surabaya, Surabaya, East Java, Indonesia.

\section{B. Formulation of The Problem}

Based on the background described the problem can be formulated as follows:

1. Does brand awareness affect brand loyalty in beach tourism in East Java?

2. Does brand image affect brand loyalty in beach tourism in East Java?

3. Does brand loyalty affect repurchase intention on beach tourism in East Java?

4. Does brand awareness affect repurchase intention through brand loyalty on beach tourism in East Java?

5. Does brand image affect repurchase intention through brand loyalty on beach tourism in East Java?

\section{Research Purposes}

This study aims to find out and analyze the influence of:

1. Brand awareness to brand loyalty in beach tourism in East Java.

2. Brand image to brand loyalty in beach tourism in East Java.

3. Brand loyalty to repurchase intention on beach tourism in East Java

4. Brand awareness to repurchase intention through brand loyalty on beach tourism in East Java.

5. Brand image to repurchase intention through brand loyalty on beach tourism in East Java.

\section{Benefits of Research}

The theoretical benefits of this research are expected to provide knowledge for the scientific community as well as contributing ideas about the influence of brand awareness and brand image on repurchase intention through brand loyalty in beach tourism in East Java. The general empirical benefits of this research are to find out the effect of brand awareness and brand image on repurchase intention through brand loyalty on beach tourism in East Java.

\section{LiteratuRE REVIEW}

\section{A. Previous Research}

This research was conducted by referring to previous research conducted by Kim and Lee (2018) which proved that brand equity (wherein there are dimensions of brand awareness) has a positive and significant effect on brand loyalty in the tourism industry

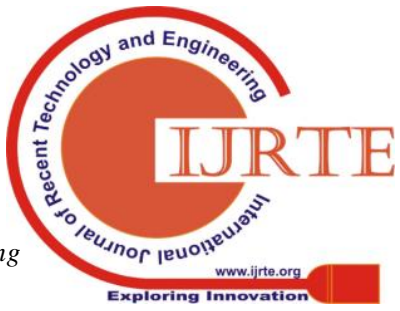


in Seoul. Other previous studies used by the reference were studies conducted by Sarvari (2012) in North Cyprus. The study also proves that brand equity in tourist destinations has a positive and significant effect on visitor behavior in the future, especially loyalty.

Previous research on the influence of brand image on brand loyalty in tourist destinations has been carried out by Roy and Hoque (2015) in Bangladesh which proves that a positive brand image in tourist destinations has a positive and significant effect on visitor brand loyalty at these tourist destinations.

Whereas previous research on the effect of brand loyalty on repurchase intention on tourist destinations has been carried out by Mehdi et al. (2013) in Iran which proves that brand loyalty has a positive and significant effect on repurchase intention.

\section{B. Brand Awareness}

Rangkuti (2004:243) says that "brand awareness is the ability of a customer to remember a particular brand or certain advertisement spontaneously or after being stimulated with key words". According to Darmadi et al., (2004: 54), the definition of brand awareness is the ability of a prospective buyer to recognize, recall a brand as part of a product category. Part of a product category needs to be emphasized because there is a strong relationship between the product category and the brand involved. according to Durianto et al., (2004:54) brand awareness (brand awareness), shows the ability of consumers (or prospective buyers) to recall (recognize) or recognize (recall) that a brand is a part of a particular product category.

From the definitions of experts regarding brand awareness, it can be concluded that brand awareness is a general goal of marketing communication, high brand awareness is expected whenever the needs of a category emerge, the brand will be brought back from memory which is then taken into consideration by various alternatives in decision making. brand awareness shows consumer knowledge about the existence of a brand.

Brand awareness is the ability of a consumer to recognize and remember a brand in different situations (Aaker, 1996). Hoeffler \& Keller (2002) states that brand awareness can be distinguished from depth and width. Depth is the ability of consumers to recognize a brand easily, and width signifies the situation when consumers consider buying a product, then a brand can appear in their minds at that moment. If a product has a brand's depth and width at the same time, then the consumer will buy a specific brand when buying a product. It can be concluded that the product has high brand awareness. Brand awareness can help consumers to recognize brands from a product category and make a repurchase decision (Percy \& Rossiter, 1992).

Hoeffler \& Keller (2002) states that brand awareness can be distinguished from depth and width. Depth is the ability of consumers to recognize a brand easily, and width signifies the situation when consumers consider buying a product, then a brand can appear in their minds at that moment. If a product has a brand's depth and width at the same time, then the consumer will buy a specific brand when buying a product. It can be concluded that the product has high brand awareness.

\section{Brand Image}

Brand image is the consumer's perception of the brand as a result of the association of brands in consumer memory (Keller, 1993). Keller also mentioned that brand image is part of brand association. In the opinion of You \& Donthu, 2001, brand association means that many things are related from memories of brands as a result of the frequency of brand awareness. In consumer perceptions, brand image can be predicted based on product attributes, benefits, and attitudes of consumers towards the product or service produced (Grace \& O'cass, 2002).

According to (Kotler and Armstrong, 2001). Brand image is a set of consumer beliefs about a particular brand. While Temporar (2003) mentions that brand image is how the brand looks. According to Tjiptono (2005) brand image is a description of consumer associations and beliefs about a particular brand. From the definitions of the experts above, it can be concluded that brand image cannot be separated from the factors forming brand image in relation to brand associations.

\section{Brand Loyalty}

Aaker (1996), assumes that brand loyalty is the attitude of consumers to brands based on their experience in using and shopping experience of a product (Deighton et al., 1994; Aaker, 1991). Assael (1998) defines brand loyalty as customer satisfaction in past experience with a brand that results in a repurchase behavior. Brand loyalty means the tendency of consumers towards a brand that limits the desire to choose another brand when buying a product (Baldinger \& Rubinson, 1996; Cavero \& Cebollada, 1997).

According to Schiffman and Kanuk (2004:227), brand loyalty is consistently consumer preferences to make purchases on the same brand on specific products or certain service categories. According to Lau and Lee (1999:351), brand loyalty has been conceptualized as an actual pattern of purchasing behavior from a brand, or buying intention behavior towards a brand. According to Aaker (in Ardha, 2008:61) brand loyalty is a measure of customer relationship to a brand. This measure is able to provide an overview of the possibility of a customer switching to another product, especially on a brand that he found there is a change, both concerning prices or other attributes.

\section{E. Repurchase Intention}

According to Hellier et al., (2003) repurchase intention is a person's planned decision to repurchase certain services, taking into account the situation that occurs and the level of preference. Repurchase Intention is the intention to repurchase a product twice or more, both for the same and different products (Zeng et al., 2009). According to Anoraga (2000) repurchase intention is a decision-making process carried out by consumers after making purchases on products offered or needed by these consumers.

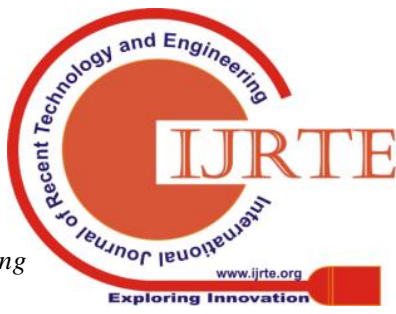


Engel et al., (1995) define repurchase intention as the desire of consumers to buy a product. Consumer repurchase intention is classified as a subjective sign of a product and can be an important sign to predict consumer behavior (Fishbein \& Ajzen, 1975). Mowen and Minor (2001) explain that repurchase intention is a series of results of a customer's thoughts from problem recognition, finding solutions, alternative valuation, and decision making. Repurchase intention is the result of positive consumer feelings towards the brand (Wang \& Kan, 2002).

\section{F. Research Model}

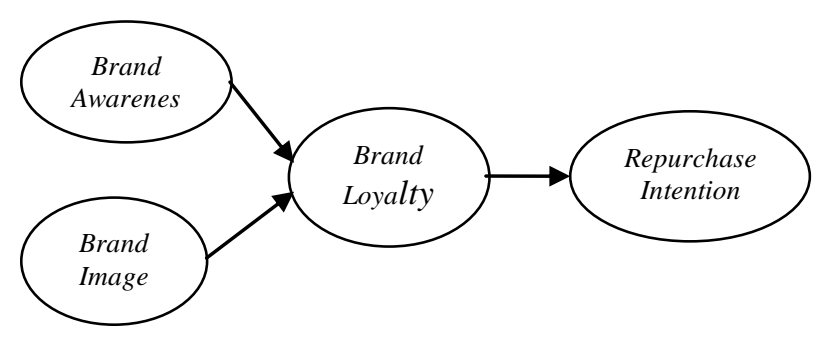

Figure1. Research Model

\section{G. Hypothesis}

The hypothesis proposed in this study are:

1. Brand Awareness has a significant effect on Brand Loyalty in Beach Tourism in East Java.

2. Brand Image has a significant effect on Brand Loyalty in Beach Tourism in East Java.

3. Brand loyalty has a significant effect on Repurchase Intention on Beach Tourism in East Java.

4. Brand Awareness has a significant effect on Repurchase Intention through Brand Loyalty on Beach Tourism in East Java.

5. Brand Image has a significant effect on Repurchase Intention through Brand Loyalty on Beach Tourism in East Java.

\section{RESEARCH METHOD}

\section{A. Research Design}

This type of research is survey research. Called survey research because this research was conducted on large and small populations, but the data studied was data from samples taken from the population.

\section{B. Variable Identification}

This study consisted of 1 exogenous variable and 3 endogenous variables:

1. Exogenous Variable $(\mathrm{X})$ :

a. Brand Awareness $\left(\mathrm{X}_{1}\right)$

b. Brand Image $\left(\mathrm{X}_{2}\right)$

2. Intervening Variables: Brand Loyalty $\left(\mathrm{Y}_{1}\right)$

3. Endogenous Variables: Repurchase Intention $\left(\mathrm{Y}_{2}\right)$

\section{Operational Definition}

1. Brand Awareness

The ability of a consumer to recognize and remember a brand in different situations.

\section{Brand Image}

A set of consumer beliefs about a particular brand.

3. Brand Loyalty

Consistent consumer preferences to make purchases on the same brand on specific products or certain service categories.

4. Repurchase Intention

The intention to repurchase a product twice or more, both for the same and different products.

\section{Types and Data Sources}

The type of data in this study is quantitative data, namely research data in the form of numbers in the form of scores that have been given a score. The data source in this study uses primary data. Data was obtained from questionnaires filled by 4-star hotel customers in East Java through surveys by distributing questionnaires to obtain data from respondents.

\section{E. Data Measurement}

The scale of data measurement used in this study is the interval scale that is one scale with the other scale has the same distance or size. The data measurement tool used is the Likert Scale, by giving scores for each category, namely:

$\begin{array}{ll}\text { Strongly agree } & : 5 \\ \text { Agree } & : 4 \\ \text { Neutral } & : 3 \\ \text { Disagree } & : 2 \\ \text { Strongly disagree } & : 1\end{array}$

\section{F. Data Collection Tools and Methods}

The data collection tool used in this study is a questionnaire is a technique of data collection carried out by giving a set of questions or written statements to the respondent to answer. The questionnaire was given to respondents and it was hoped that each respondent would answer the questions in the questionnaire according to their own opinions and perceptions. Data collection methods used in research are survey and direct interviews with the parties concerned.

\section{G. Research Population and Samples}

In this study, the study population refers to all beach tourists in East Java, then sampling for this study was 200 people. Understanding the sample according to Sugiyono (2010: 81) is as follows: "Samples are part of the number and characteristics possessed by the population". Sampling is done using Non probability sampling withdrawal techniques. Nonprobability sampling according to Sugiyono (2010: 218) is a sampling technique that does not provide the same opportunity or opportunity for each element or member of the population to be chosen as a sample". The sampling technique in this study uses sampling quota because it determines the sample of the population that has certain characteristics to the desired amount.

1. Consumers who have visited one of the beaches

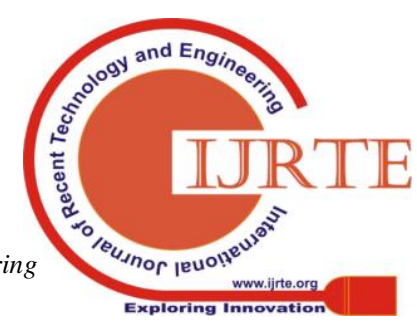


that are generally known are in East Java

a. Pasir Putih Beach, Situbondo

b. Plengkung Beach, Banyuwangi

c. Bandealit Beach, Jember

d. Sendang Biru Beach, Malang

e. Pulau Merah Beach, Banyuwangi

f. Balekambang Beach, Malang

g. Papuma Beach, Jember

2. Minimum age of 21 years.

\section{H. Data Collection Techniques}

The data collection technique used in this study is a questionnaire technique, which provides a set of questions or written statements to respondents to answer.

\section{Data Analysis Technique}

The data analysis technique used to discuss the problems in this study is the Structural Equation Model (SEM). Structural Equation Model (SEM) is a statistical technique that allows testing of a series of relatively complex relationships simultaneously. Complex relationships can be built between one or several dependent variables with one or several independent variables. There may also be a variable that has a dual role, namely as an independent variable in a relationship, but becomes a dependent variable in another relationship given the existence of a tiered causality relationship. Each dependent and independent variable can be in the form of a factor or construct that is constructed from several indicator variables. Likewise, among variables it can take the form of a single variable that is observed or that is measured directly in a research process.

The data analysis technique used in this study is the Structural Equation Model (SEM). In SEM the measurement model, overall model, and structural model are tested. In addition, this study also uses path analysis to explain the relationships between variables. With the use of the SEM method a comprehensive model can be displayed and can explain the relationship between one construct and another.

\section{RESUltS AND FINDINGS}

\section{A. Brand Awareness Descriptive Statistics}

Brand Awareness variables are measured using 5 indicators. The number of average values in the Brand Loyalty variable is 3.76 with an average standard deviation of 0.83 . This shows that the respondent's answer to Brand Awareness is "Agree". The following beach tourism indicators in East Java (some or all): Pasir Putih Beach, Situbondo; Plengkung Beach, Banyuwangi; Bandealit Beach, Jember; Sendang Biru Beach, Malang; Pulau Merah Beach, Banyuwangi; Balekambang Beach, Malang; Papuma Beach, Jember; I know that the magazine has the highest mean value compared to other indicators, which is 3.84 . While the following beach tourism indicators in East Java (one, several or all): Pasir Putih Beach, Situbondo; Plengkung Beach, Banyuwangi; Bandealit Beach, Jember; Sendang Biru Beach, Malang; Pulau Merah Beach, Banyuwangi; Balekambang Beach, Malang; Papuma Beach,
Jember; I know that it is informed on television that it has the lowest mean, which is equal to 3.60 .

\section{B. Brand Image Descriptive Statistics}

Brand Image variables are measured using 4 indicators. The average value of the Brand Image variable is 3.71 with an average standard deviation of 0.94 . This shows that the respondent's answer to the Brand Image is "Agree". Indicators in my opinion most people have a positive opinion about the following beach destinations: Pasir Putih Beach, Situbondo; Plengkung Beach, Banyuwangi; Bandealit Beach, Jember; Sendang Biru Beach, Malang; Pulau Merah Beach, Banyuwangi; Balekambang Beach, Malang; Papuma Beach, Jember; has the highest mean value compared to other indicators, which is equal to 3.92. While the Indicator in my opinion the following beach tourist destinations pay attention to environmental sustainability: Pasir Putih Beach, Situbondo; Plengkung Beach, Banyuwangi; Bandealit Beach, Jember; Sendang Biru Beach, Malang; Pulau Merah Beach, Banyuwangi; Balekambang Beach, Malang; Papuma Beach, Jember; has the lowest mean, which is equal to 3.43 .

\section{Descriptive Statistics Brand Loyalty}

Brand Loyalty variables measured by using 3 indicators. The average number of Brand Loyalty variables is 3.62 with an average standard deviation of 1.00. This shows that the answer to the respondent's answer to Brand Loyalty is "Agree". Indicator "I will suggest friends to visit the following tourist destinations: Pasir Putih Beach, Situbondo; Plengkung Beach, Banyuwangi; Bandealit Beach, Jember; Sendang Biru Beach, Malang; Pulau Merah Beach, Banyuwangi; Balekambang Beach, Malang; Papuma Beach, Jember "has the highest mean value compared to other indicators, which is equal to 3.69. Meanwhile, indikotor "I will say positive things about the following tourist destinations: I will say positive things about the following tourist destinations: Pasir Putih Beach, Situbondo; Plengkung Beach, Banyuwangi; Bandealit Beach, Jember; Sendang Biru Beach, Malang; Pulau Merah Beach, Banyuwangi; Balekambang Beach, Malang; Papuma Beach, Jember "has the lowest mean of 3.55.

\section{Repurchase Intention Descriptive Statistics}

Repurchase Intention variable is measured using 3 indicators. The total value of Repurchase Intention is 3.69 with an average standard deviation of 0.82 . This shows that the respondent's answer to the Repurchase Intention is "Agree". Indicator "I will visit the following tourist destinations again because of their natural environment: Pasir Putih Beach, Situbondo; Plengkung Beach, Banyuwangi; Bandealit Beach, Jember; Sendang Biru Beach, Malang; Pulau Merah Beach, Banyuwangi; Balekambang Beach, Malang; Papuma Beach, Jember "Has the highest mean value compared to other indicators which is equal to 3.75. Meanwhile, the indicator "I will visit the following tourist destinations again because if compared to the costs that I provide with the satisfaction that I get, the

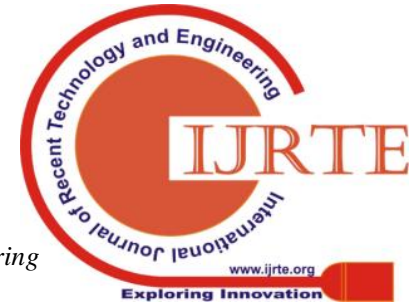


cost that I spend is very cheap: Pasir Putih Beach, Situbondo; Plengkung Beach, Banyuwangi; Bandealit Beach, Jember; Sendang Biru Beach, Malang; Pulau Merah Beach, Banyuwangi; Balekambang Beach, Malang; Papuma Beach, Jember "has the lowest mean of 3.62.

\section{E. Goodness of Fit}

Goodness of Fit is used to test whether the research model is a good model for presenting the major theories studied.

Table 1. Model Fit Testing

\begin{tabular}{|c|c|c|c|}
\hline Model Testing & Score & $\begin{array}{l}\text { Cut of } \\
\text { Value }\end{array}$ & Description \\
\hline GFI & 0.90 & $\geq 0.9$ & Good Fit \\
\hline AGFI & 0.87 & $\geq 0.9$ & Marginal Fit \\
\hline NFI & 0.93 & $\geq 0.9$ & Good Fit \\
\hline IFI & 0.98 & $\geq 0.9$ & Good Fit \\
\hline CFI & 0.98 & $\geq 0.9$ & Good Fit \\
\hline RFI & 0.92 & $\geq 0.9$ & Good Fit \\
\hline RMSEA & 0.05 & $<0.08$ & Close fit \\
\hline
\end{tabular}

Source: Data, processed

Based on Table 1, it can be explained that the research model proposed in this study is acceptable.

\section{F. Hypothesis Testing}

Table 2. Hypothesis Test Results

\begin{tabular}{|c|c|c|c|c|c|}
\hline $\begin{array}{l}\text { Hypo } \\
\text { thesi } \\
\mathrm{S}\end{array}$ & $\begin{array}{l}\text { Relationshi } \\
\text { p Pattern }\end{array}$ & $\begin{array}{l}\text { Loadin } \\
g \\
\text { factor }\end{array}$ & $\begin{array}{l}e^{\mathrm{t}-\text { valu }} \\
\end{array}$ & $\begin{array}{l}\text { Cut } \\
\text { off } \\
\text { Value }\end{array}$ & $\begin{array}{l}\text { Descri } \\
\text { ption }\end{array}$ \\
\hline 1. & $\begin{array}{l}\text { Brand } \\
\text { Awareness } \\
\rightarrow \\
\text { Brand } \\
\text { Loyalty }\end{array}$ & 0.67 & 2.13 & 1.96 & Sig \\
\hline 2. & $\begin{array}{l}\text { Brand } \\
\text { Image } \\
\rightarrow \\
\text { Brand } \\
\text { Loyalty }\end{array}$ & 0.73 & 2.69 & 1.96 & Sig \\
\hline 3. & $\begin{array}{l}\text { Brand } \\
\text { Loyalty } \\
\rightarrow \\
\text { Repurchas } \\
\text { e Intention }\end{array}$ & 0.85 & 3.43 & 1.96 & Sig \\
\hline 4. & $\begin{array}{l}\text { Brand } \\
\text { Awareness } \\
\rightarrow \\
\text { Brand } \\
\text { Loyalty } \\
\rightarrow \\
\text { Repurchas } \\
\text { e Intention }\end{array}$ & 1.01 & 5.02 & 1.96 & Sig \\
\hline 5. & $\begin{array}{l}\text { Brand } \\
\text { Image } \\
\rightarrow \\
\text { Brand } \\
\text { Loyalty } \\
\rightarrow \\
\text { Repurchas } \\
\text { e Intention }\end{array}$ & 0.77 & 2.11 & 1.96 & Sig \\
\hline
\end{tabular}

Source: Data, processed

\section{Description:}

1. The value of the loading factor of the influence of Brand Awareness on Brand Loyalty is 0.67 while the value of t-value is equal to 2.13 (> 1.96). It can be stated that Brand Awareness has a positive and significant effect on Brand Loyalty.

2. The value of loading factor influences Brand Image on Brand Loyalty by 0.73 while the t-value value is 2.69 (> 1.96) then it can be stated that Brand Image has a positive and significant effect on Brand Loyalty.

3. The value of the loading factor of the effect of Brand Loyalty on Repurchase Intention is 0.85 while the t-value is 3.43 (> 1.96). It can be stated that Brand Loyalty has a positive and significant effect on Repurchase Intention.

4. The value of loading factor of the effect of Brand Awareness on Repurchase Intention through Brand Loyalty is 1.01 while the t-value is 5.02 (> 1.96), it can be stated that Brand Awareness has a positive and significant effect on Repurchase Intention through Brand Loyalty.

5. The value of loading the influence factor of Brand Image on Repurchase Intention through Brand Loyalty is 0.77 while the value of t-value is 2.11 (> 1.96). It can be stated that the Brand Image of Repurchase Intention through Brand Loyalty has a positive and significant effect.

\section{G. Discussion}

1. Brand awareness has a significant effect on brand loyalty on beach tourism in East Java.

Brand Awareness descriptive statistics have a mean value of 3.76 and a standard deviation of 0.83 . The average value proves that the respondent agrees to the measurement of Brand Awareness, which is knowing that the beach tourism destinations: informed on television, informed in the newspaper, informed in the magazine, informed on the internet, and has an annual routine festival agenda. Whereas Brand Loyalty has a mean value of 3.62 and standard deviation of 1.00. The mean value proves that the respondent agrees to the measurement of Brand Loyalty, namely: will say positive things about the beach tourism destinations, will advise friends to visit these beach tourism destinations, and will visit these beach destinations for upcoming tours.

Hypothesis test results prove that loading factors influence brand awareness of brand loyalty by 0.67 and t-value of 2.13 (>1.96) then the results are stated to be significant and positive. These results prove that respondents who have brand awareness of the beach tourism destinations have brand loyalty towards the beach tourism destinations.

The results of this study support previous research conducted by Kim \& Lee (2018) and Sarvari (2012) which in their research proved the positive and significant influence of the influence of brand awareness on brand loyalty 
towards tourist destinations.

2. Brand image has a significant effect on brand loyalty on beach tourism in East Java.

Brand Image descriptive statistics have a mean value of 3.71 and a standard deviation of 0.94 . This value proves that the respondent agrees to the measurement of the Brand Image variable, namely: most people have a positive opinion about the beach destinations, the beach destinations have a unique image, the beach destinations are popular, the destinations beach tourism is concerned with environmental sustainability. Where as Brand Loyalty has a mean value of 3.62 and standard deviation of 1.00 . The mean value proves that the respondent agrees to the measurement of Brand Loyalty, namely: will say positive things about the beach tourism destinations, will advise friends to visit these beach tourism destinations, and will visit these beach destinations for upcoming tours.

The hypothesis testing proves the significant and positive influence of brand image on brand loyalty. With a value of 0.73 and t-value of 2.69 with a cut-off of 1.96 . These findings indicate that the brand image of these tourist destinations positively and significantly affects brand loyalty at the beach tourism destinations.

The results of this study support previous research conducted by Roy and Hoque (2015) in Bangladesh which proves that positive brand image in tourist destinations has a positive and significant effect on the brand loyalty of visitors to these tourist destinations.

3. Brand loyalty has a significant effect on repurchase intention on beach tourism in East Java.

Brand loyalty has a mean value of 3.62 and a standard deviation of 1.00. The mean value proves that the respondent agrees to measuring brand loyalty, namely: will say positive things about the beach tourism destinations, will advise friends to visit the beach destinations, and will visit the beach destinations for upcoming tours. While the average value of the repurchase intention variable is 3.69 with a standard deviation of 0.82 . The average value proves that the respondent agrees to the measurement of the repurchase intention variable which is going to visit the beach tourism destinations again because: the natural environment, makes me relax my mind and body, when compared to the costs incurred with satisfaction obtained, the costs incurred very cheap.

The results of hypothesis testing prove that brand loyalty has a positive and significant effect on repurchase intention with a loading factor of 0.85 and a t-value of 3.43 with a cut-off of 1.96 . These findings indicate that if visitors have brand loyalty to these tourist destinations, it will positively and significantly affect repurchase intention at the beach tourism destinations.

The results of this study support previous research conducted by Mehdi et al. (2015) in Iran which proves that brand loyalty has a positive and significant effect on repurchase intention.

4. Brand awareness has a significant effect on repurchase intention through brand loyalty on beach tourism in East Java.
Brand Awareness descriptive statistics have a mean value of 3.76 and a standard deviation of 0.83 . The average value proves that the respondent agrees to the measurement of Brand Awareness, which is knowing that the beach tourism destinations: informed on television, informed in the newspaper, informed in the magazine, informed on the internet, and has an annual routine festival agenda. While the average value of the repurchase intention variable is 3.69 with a standard deviation of 0.82 . The average value proves that the respondent agrees to the measurement of the repurchase intention variable which is going to visit the beach tourism destinations again because: the natural environment, makes me relax my mind and body, when compared to the costs incurred with satisfaction obtained, the costs incurred very cheap. While Brand loyalty has a mean value of 3.62 and a standard deviation of 1.00. The mean value proves that the respondent agrees to measuring brand loyalty, namely: will say positive things about the beach tourism destinations, will advise friends to visit the beach destinations, and will visit the beach destinations for upcoming tours.

The results of hypothesis testing prove that brand awareness has a positive and significant effect on repurchase intention through brand loyalty with a loading factor value of 1.01 and t-value of 5.02 with a cut-off of 1.96. This means that visitors' brand awareness of beach tourism destinations is positively and significantly influences brand loyalty in beach tourism destinations, which in turn affects repurchase intention to these beach tourism destinations.

The results of this study support previous research conducted by Kim \& Lee (2018) and Sarvari (2012) which in their research proved the positive and significant influence of the influence of brand awareness on brand loyalty towards tourist destinations.

5. Brand image has a significant effect on repurchase intention through brand loyalty on beach tourism in East Java.

Brand Image descriptive statistics have a mean value of 3.71 and a standard deviation of 0.94 . This value proves that the respondent agrees to the measurement of the Brand Image variable, namely: most people have a positive opinion about the beach destinations, the beach destinations have a unique image, the beach destinations are popular, the destinations beach tourism is concerned with environmental sustainability. Where as Brand loyalty has a mean value of 3.62 and a standard deviation of 1.00. The mean value proves that the respondent agrees to measuring brand loyalty, namely: will say positive things about the beach tourism destinations, will advise friends to visit the beach destinations, and will visit the beach destinations for upcoming tours. While the average value of the repurchase intention variable is 3.69 with a standard deviation of 0.82 . The average value proves that the respondent agrees to the measurement of the repurchase intention variable which is going to visit the beach tourism destinations

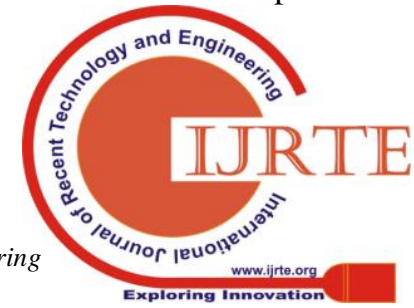


again because: the natural environment, makes me relax my mind and body, when compared to the costs incurred with satisfaction obtained, the costs incurred very cheap.

The results of hypothesis testing prove that brand image has a positive and significant effect on repurchase intention through brand loyalty with the value of loading factor 0.77 and t-value 2.11 with a cut-off of 1.96. This means that the brand image of beach tourism destinations is positively and significantly influences brand loyalty in beach tourism destinations, which in turn affects repurchase intention to those beach tourism destinations.

The results of this study support previous research conducted by Roy and Hoque (2015) in Bangladesh which proves that positive brand image in tourist destinations has a positive and significant effect on the brand loyalty of visitors to these tourist destinations.

\section{CONCLUSIONS AND SUGGESTIONS}

\section{A. Conclusions}

Based on the results of hypothesis testing it can be concluded that:

1. Brand awareness has a significant effect on brand loyalty on beach tourism in East Java, accepted.

2. Brand image has a significant effect on brand loyalty on beach tourism in East Java, accepted.

3. Brand loyalty has a significant effect on repurchase intention on beach tourism in East Java, accepted.

4. Brand awareness has a significant effect on repurchase intention through brand loyalty on beach tourism in East Java, accepted.

5. Brand image has a significant effect on repurchase intention through brand loyalty on beach tourism in East Java, accepted.

\section{B. Suggestions}

Academic Suggestion

Academic advice is proposed for future research on the influence of brand awareness, brand image, brand loyalty, and repurchase intention. It is recommended to be tested on different objects to test the firmness of these theories.

Practical Suggestions

1. Brand awareness

Beach tourism managers, especially those who are the object of this study, should pay attention to information conveyed through: television, newspapers, magazines and the internet, as well as routine annual festival agendas because descriptive statistics of this study prove respondents' awareness of the existence of beach tourism destinations this is obtained from television, newspapers, magazines, the internet, and the annual routine festival agenda.

2. Brand image

The beach tourism managers, especially those who are the object of this study, should pay attention to the brand image, namely: the beach tourism destinations have a unique image, the beach destinations are popular, and the beach tourism destinations pay attention to environmental sustainability. Because based on the results of the study it has a positive and significant effect on loyalty and intention to repeat the visit.

3. Brand loyalty

The managers of beach tourism, especially those who are the object of this study, should pay attention to brand loyalty, namely: will say positive things about the beach tourism destinations, will advise friends to visit these beach destinations, and will visit beach destinations for future tours. Therefore, beach tourism managers, especially those who are the object of this study, should pay attention to the influence of brand loyalty in this research, namely brand awareness and brand image.

4. Repurchase intention

The beach tourism managers, especially those who are the object of this study, should pay attention to the repurchase intention, namely visitors will visit these beach destinations again because: the natural environment, makes me relax my body and soul, when compared to the costs incurred with satisfaction, costs issued very cheaply. Therefore measurements must get the attention of the managers.

\section{REFERENCES}

1. Aaker, David, Manajemen Ekuitas Merek, Jakarta: Spektrum, 1997.

2. Aaker, A. David, Manajemen Ekuitas Merek, Alih bahasa oleh Aris Ananda, Jakarta: Mitra Utama, 2008.

3. Chi, H.K., Yeh, H.R., \& Yang, Y.T, The Impact of Brand Awareness on Consumer Purchase Intention: The Mediating Effect of Perceived Quality and Brand Loyalty, The Journal of International Management Studies, Vol. 4, No. 1, 2009, pp. 135-144.

4. Durianto, Darmadi, Strategi Menaklukkan Pasar Melalui Riset Ekuisitas dan Perilaku Merek, Jakarta, Gramedia, 2004

5. Hellier, Phillip K., Geursen, Gus M., Carr, Rodney., and Rickard, John A, Customer Repurchase Intention: A General Structural Equation Model, European Journal of Marketing, 37 (11/12), 2003, pp. 1762-1800.

6. Jing, Z., Pitsaphol, C., \& Shabbir, R, The Influence Of Brand Awareness, Brand Image And Perceived Quality on Brand Loyalty: A Case Study Of Oppo Brand In Thailand, Wuhan, China, 2014.

7. Khan, Afaq Ahmed., Jadoon, Saneela., and Tareen, Naqash A.K, Impact of Advertising on Brand Awareness and Commitment in Female Apparel Industry, International Journal of Academic Research in Business and Social Sciences; Vol. 6, No. 3, 2016.

8. Kim, Hwa-Kyung., \& Timothy J. Lee, Brand Equity of a Tourist Destination, Sustainability, Vol. 10, 2018, pp. 1-21.

9. Kotler, Phillip \& Gary Amstrong, Principles of Marketing. $8^{\text {th }}$ ed, Pearson Education (US), 2001.

10.Kotler, P, Marketing Management, $11^{\text {th }}$ ed., New Jersey: Prentice Hall, 2003.

11.Lau, G., \& Lee, S, Consumers Trust In A Brand And Link To Brand Loyalty, Journal of Marketi Focused Management, 1999.

12.Mehdi1, Jalali Seyyed., Khadem Mojgan., \& Javidani Masoud, Investigation of the Effective Factors on Brand Loyalty and Repurchase Intention (Case study: Iranian Consumers), Research Journal of Recent Sciences, Vol. 2(2), 2013, pp. 10-17.

13.Rangkuti, F., The Power of Brand. Jakarta, PT Gramedia Pustaka Utama, 2004.

14.Roy, Biplab \& Rajidul Hoque, Building a Strong Brand Image of Cox's Bazar as a Tourist Destination: An Empirical Analysis on Cox's Bazar, American Journal of Tourism Management, 4(2), 2015, pp. 27-34.

15.Sarvari, Neda Gholizadeh, Destination Brand Equity, Satisfaction And Revisit Intention: An Application In TRNC As a Tourism Destination, Thesis, Institute of Graduate Studies and Research. Eastern Mediterranean University. Gazimağusa, North Cyprus, 2012.

16.Schiffman, I.G., \& Leslie L. Kanuk, Consumer Behavior, Englewood Cliffs, New Jersey: Prentice Hall, 2004. 
17.Tjiptono, Fandy, Brand Management \& Strategy, Yogyakarta, Andi Offset, 2005.

18. Yun-Tsuo, Huang., Kuo-Wei, Lee. \& Wen-Yuan, Chan, An Empirical Study of Consumer's Repurchase Intention of Tablet PC, 2011.

19.Zeng, F.,Zuohao H., Rong C., \& Zhilin Y, Determinants of Online Service Satisfaction and Their Impacts on Behavioral Intentions, Total Quality Management \& Business Excellence, 20 (8), . 2009, pp. 953-969.

\section{ACKNOWLEDGMENT}

This research was carried out thanks to financial support from the Faculty of Business - Widya Mandala Catholic University Surabaya.

\section{AUTHORS PROFILE}

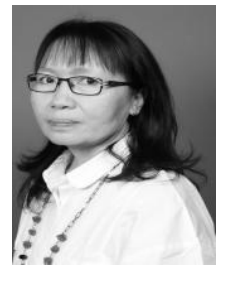

Christina Esti Susanti. Indonesian nationality and currently living in Surabaya, East Java, Indonesia. Since 1989 up to now as a lecturer in the Faculty of Business Widya Mandala Catholic University Surabaya. It also teaches in the post graduate and doctoral program at several universities.

As for the history of education, completing undergraduate courses in management studies at the Atma Jaya University, Yogyakarta, Indonesia; post graduate courses in marketing management at the Brawijaya University, Malang, Indonesia; and doctoral program courses in marketing management at the Airlangga University, Surabaya, Indonesia. Research Interests: Marketing Management, Consumer Behaviour, and Service Marketing in hospitality industry. 